\title{
Developing Sangiran Archaeological Site as Tourism Destination: Social Expectations and Governmental Policy's Constraints
}

\author{
Basuki Agus Suparno*, Kurnia Arofah, Isbandi Sutrisno \\ Department of Communication Science, University of Pembangunan Nasional “Veteran” Yogyakarta, Indonesia
}

\begin{abstract}
Sangiran is an archaeological site that was established as a cultural heritage by Indonesia and was recognized as a world cultural heritage by UNESCO. Since the 1930s, Sangiran local people have become familiar with the visitors who investigate the site. In 2009, the Ministry of Education established Conservation Office of Sangiran Early Man Site (Balai Pelestarian Manusia Purba Sangiran-BPSMPS). Later in 2010, the Indonesian government released the Law 2010/No. 11 about Cultural Heritage for all Cultural Heritage around Indonesia. Both BPSMPS and the law bring changes in Sangiran. This research aims to expose the social expectation and governmental policy constraints after the BPSMPS and the Law 2010/No 11 that has been implemented for ten years. This research was conducted by critical ethnography. Findings of this research are, a) Sangiran local people feel disadvantages and distrust by the implementation of Cultural Heritage Law, yet they adapt and obey the law; b) two expectations should be synchronized, on one other side, the first tourism development must be accelerated, and the second is the implementation conservation principle must be reinvented; c) clear policy related to every stakeholder's roles must be formed to avoid sectoral ego and clash among stakeholders. It must be secured and maintain to synergize to any type of resources there.
\end{abstract}

Keywords: conservation, cultural heritage law, heritage tourism, Sangiran, social expectation.

\section{INTRODUCTION}

One of the most prominent sectors for Indonesia's economy and prosperity is the tourism industry. It is regarded as pivotal for the national economy since it contributes to local well-being, such as creating job opportunities and bolstering local culture [1]. While studies related to it - based tourism and ecotourism are abundant. Otherwise, research related to cultural heritage is relatively rare.

Meanwhile, heritage tourism that frequently depends on living experience and history of building in the past of a cultured heritage territory is highly in demand [2]. The power of attraction of heritage tourism relies on the utilization of tangible and intangible in the past as tourism resources [3]. The practices of heritage tourism also could be performed in dual directions. First, it helped to conserve and develop the value of the site, both for the local community and tourists. Second, it promotes economic revenue, mostly for local society and national interest [4].

For Indonesia, Sangiran Site is one of the blended tourism industries among heritage, culture, and tourism. Since 1977, after stated as cultural heritage [5], Sangiran Site gradually grew

\footnotetext{
* Correspondence address:

Basuki Agus Suparno

Email : basukiagussuparno@upnyk.ac.id

Address : Dept. Communication Science, University of Pembangunan Nasional "Veteran" Yogyakarta, Jl. Babarsari 2, Sleman, DIY, Indonesia, 55281
}

into heritage tourism. Well known as the place where the early man had ever lived, scientist proposed that missing link that was postulated by Charles Darwin, exist here. It was proving the homo sapien existence puzzle in evolutionary theories located in Sangiran.

Hominid fossils such as Pithecanthropus erectus ranged from 400 thousand to 1.5 million years old was found in this location. UNESCO perceives that Sangiran has value and unique worth since it has the soil sequences that unravel the earth profile back until 2.4 million years ago.

As heritage tourism, Sangiran could also be developed based upon the concepts the community tourism. Many traditions, myths, stories, and life experiences can be offered to tell and promote. Shortly, Sangiran offers a story, history, culture, life experience, and kind of archetypes.

In the surrounding Sangiran area, some local people live side by side to the ancient human and giant bones from mammoths. Previously, they perceive the bones were remains part of mythical monstrous creatures. They called the bones as balung buto. The myth related to balung buto was frequently retold and passed to the next generation by the elders until the first Dutch researchers came to the site in the 1930s [6]. Since then, balung buto, as a term referred to fossils found there, begin to recognize, and slowly it fades along with the growth of Sangiran as a research and tourism destination. At the same time, they begin to understand that balung buto has economic values. 
The most prominent development of Sangiran as heritage tourism was marked by the establishment of a modest Sangiran museum in 1988, which modernized into four clustered museums in 2011. The Biggest cluster is the center Museum located in Krikilan Village, Sragen.

The other two clusters are supporting museums located in Ngebung Village and Bukuran Village in Sragen district, and the last one is supporting museums located in Dayu, Karanganyar district. From then until 2016, Sangiran museum gathers more than 250.000 local and international visitors, with Rp. 1 billion average revenue each year [7]. In 2018, Sangiran museum management expecting 1000 tourists will visit Sangiran daily [8].

Ideally, heritage tourism could develop the local economy and cut down on poverty [9]. In this case, the museum is represented as the centre for heritage tourism. Since the museum exists, local people who live nearby improved their income. Profession and jobs grow varies from the tour guide, homestay and food stall owner, crafter, souvenir sellers and other related to tourism [10]. Furthermore, the development of tourism makes an impact in all physical, economic, or social [11].

Various studies related to Sangiran encompassing development, potential, and the prospect have been conducted from archaeological, historical till tourism studies. The latest study was from Sugiarti et al. [12] who proposed a model for all stakeholders that should participate to optimize Sangiran as a world heritage asset through education and recreation. However, it also stated that due to economic reasons and struggle, people could violate the Law and sell the fossils [12]. Previously, Mulyantari in 2016 analyzed the potential of the Sangiran site as a tourism destination. This research also found that local people are a vital part of tourism development. It also stated that the Law 2010/No. 11 about Cultural Heritage must be enforced to avoid the fossil stolen in Sangiran [13]. It was proposed that the conservation of Sangiran should synchronic with Law no 11/ 2010 of Cultural Heritage and local government law and regulation [14].

Problems related to the implementation of cultural heritage Law were mentioned by Raharjo, who has researched several cultural heritages in Indonesia [15]. One of the problems is the Law introduces several new variables, which make more complex problems in cultural heritage sites. For example, conservation should also center on the physical environment element, not specifically concerned with the ancient relics only. On another side, many people who live around the area can't be neglected at all. Interrelations between environment and people raise a social problem too.

Another new system was also introduced by this Law, where the cultural heritage will be ranked in three levels: National, provincial, and city/district. This policy has implication for financial aid and assistance for it. Sragen district frequently did not engage in provincial policy. Meanwhile, this Law implemented nationally in all cultural heritage in Indonesia [15].

Studies related to the implementation of the Cultural Heritage Law has been conducted by numerous scholars. Most studies examined whether Law no 11/2011 effective or not. Prasetyo in 2018 stated the law hasn't worked effectively since the law enforcer who has strong knowledge related to cultural heritage are only a few. Moreover, the public awareness related to this law is low [16].

Harjanto et al. also stated that this Law was not socialized enough and mostly the cultural heritage was lack of human resources [17]. Some implementation of the Cultural Heritage Law also asynchronous with the implementation of the regulation below this law which make the coordination between governments institutions become hard [18]. It also happened in Sangiran, since the Sangiran site was developed under supervision by three government institutions: Ministry of education through the establishment of Conservation Office of Sangiran Early Man Site (Balai Pelestarian Situs Manusia Purba Sangiran BPSMPS) in Sangiran Museum, The government of Jawa Tengah province, and District tourism office of Sragen and Karanganyar.

As stated earlier, mainly since 2009, studies related to Sangiran development are diverse. However, most of the studies haven't portrayed the two problems that will be encountered when the Sangiran site developed as a heritage tourism destination. Those are related to encouraging economic vitality of community by gaining profit; and Sustainability of Sangiran site into tourism industry which both has to deal with the strict implementation of the Cultural Heritage Law.

Most of the study also rarely portrayed the actual expectation and constraints from Sangiran local people who already live at the site from 
generation to generation, after the implementation of Cultural Heritage Law $2010 /$ No. 11, and after the BPSMPS was established in Sangiran. Therefore, this study was conducted to identify the changes in Sangiran after ten years of Cultural Heritage Law implementation and after the BPSMPS was established. We examined the relation and interrelation in Sangiran and the emerging expectations of Sangiran stakeholders, which are limited by the Cultural Heritage Law implementation. The findings of this study tried to portray Sangiran condition and minimize the out of sync potential mostly between the local people who live in Sangiran Site, the provincial government, national government and other stakeholders who are concerned in Sangiran site.

\section{MATERIAL AND METHOD}

This research used a qualitative approach. It probes people's knowledge, experiences, and situations in their natural setting [19]. This study applied the critical ethnography. Generally, it is considered as one of the effective ways to grasp social reality. Studying a village could be assumed as closely eyeing the microcosm of human culture [20]. The objective of critical ethnography is to unravel the relations of power by participating comprehensively in a research environment. Researchers could oversight the situation of unequal relations of power in the cultural setting [21]. Critical ethnography also could be used as a method to discover the constraints, injustice, or even inequality of power [22].

\section{Data Collection}

There are two kinds of data used in this research: primary and secondary. Primary data was collected during in November and December, 2020 through two Focus Group Discussions (FGD).

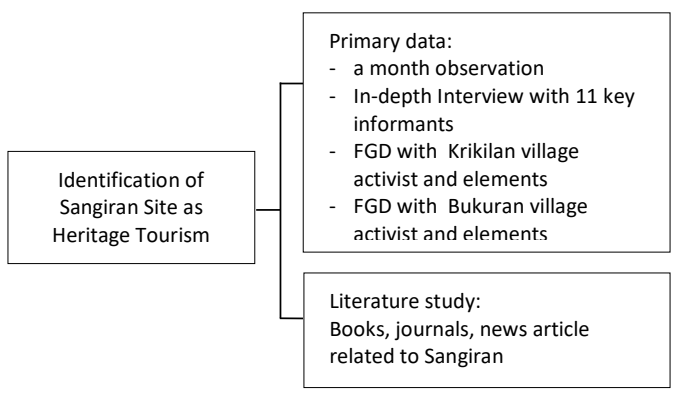

Figure 1. Method of Collecting Data

Around three hours of FGD was held in the Krikilan village meeting hall. Researchers also conduct a similar FGD in the Ngebung village meeting hall. Both FGD attended by a variety of informants: Head of Villages, a representative from local youth organization, local woman activist, Public Servant, handcraft man, and homestays owner.

Primary data was collected to catch up with local people daily activity covering perception, myth, and a tradition that they are believing, and economic activity that they are deserving. To enrich the data, secondary data were also collected during this research. The data obtained through literature study from books, journals, internet sites, news, and so on.

\section{RESULT AND DISCUSSION}

In this session, four segments will be presented. First, we described the variety of potentialities in the Sangiran site from its people, culture, and nature. Second, the pattern of relations and social relations that constitute society. It portrays a kind of interaction that can be seen to notice the difficulty or possibility to cooperate and collaborate. Third, social expectations that encourage the Sangiran stakeholders have shared value related to Sangiran as an International tourism destination. Fourth, governmental and policy constraints which affecting Sangiran Site development. Below is the result from observation, in-depth interview, FGD, and literature review.

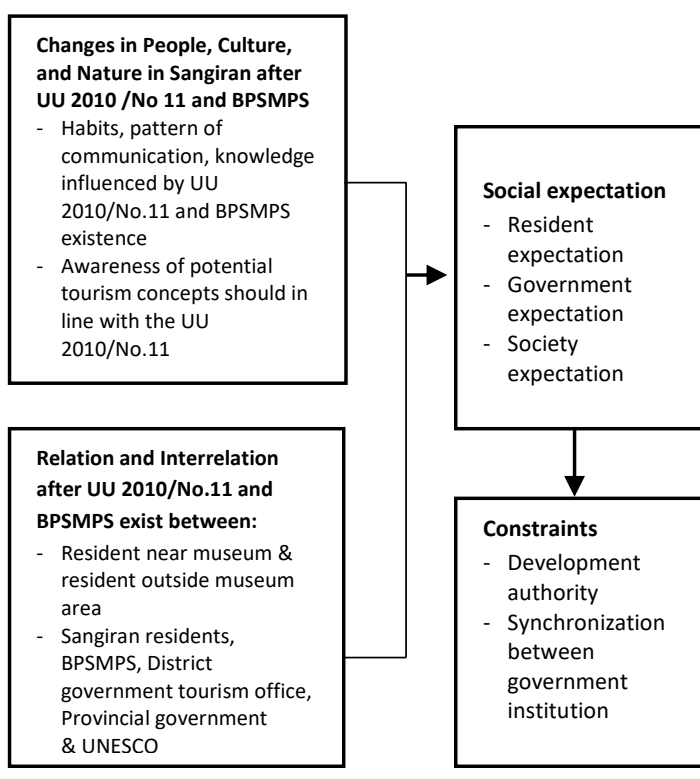

Figure 2. Results of collected data

\section{Changes: People, Culture and Nature}

Sangiran site located in two districts, Sragen and Karanganyar, in Central Java province. This location is very close to Solo city, as central of Javanese Culture. People who live in Sangiran 
behave in line with Javanese norms and ethics, which give priority to live in a peaceful and harmonious community in togetherness, honesty, tolerance, patience, and so on [23].

Viewed from the structure and functional premises, environment was perceived as a dominant factor in determining the attitude and behavior of the person in the society [24]. In fact, the center of the Sangiran site is located in the Sragen district, where one of the main problems is poverty for the ones who live in the infertile land [25].

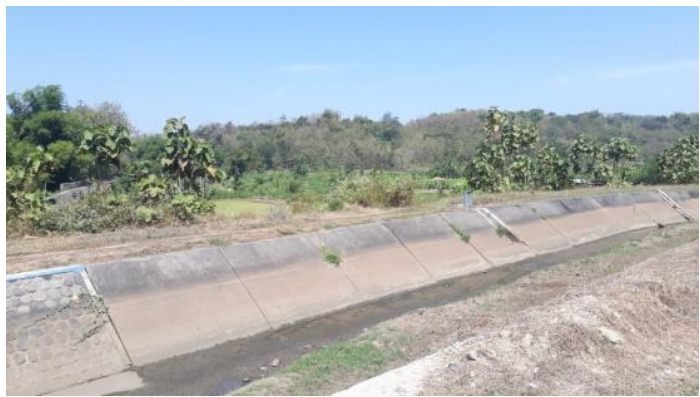

Figure 3. The irrigation circling Sangiran Site normally drought in the dry season

This environment affected people who live in the area has not almost supported the need of daily life. Some of them survive as a farmer who relies on rainfed, some of them choose to work outside Sangiran as labour, merchant, businessman, and so on. SPD, the former Head of Ngebung Village, Sangiran mentioned soil condition was changed in rainy season. Landside often happens and naturally brings up the buried fossils. In previous times, fossils will just show up in scattered places after raining, and people who found them will keep them or sold them illegally to the collector. However, after the implementation of cultural heritage law, this habit is faded and disappeared gradually.

The message warns people for reflecting on Cultural Heritage Law No. 11/2010 enforcement could be seen throughout the Sangiran site. The article states that cultural heritage must be protected. The public is restricted to harm, stealing, remove, restore or keep everything found on the site [26] are printed and installed in the form of a warning board surround the radius $56 \mathrm{~km}$ square of the Sangiran area. People who live in the site area after the law no 11/2011 established must obey the law whether they want it or not. WDD (Head of Krikilan Village, Sangiran), explained after the implementation of the law, local people are on disadvantages and distrust. They now cannot remove or even change their own land only because it is located inside the heritage area site.

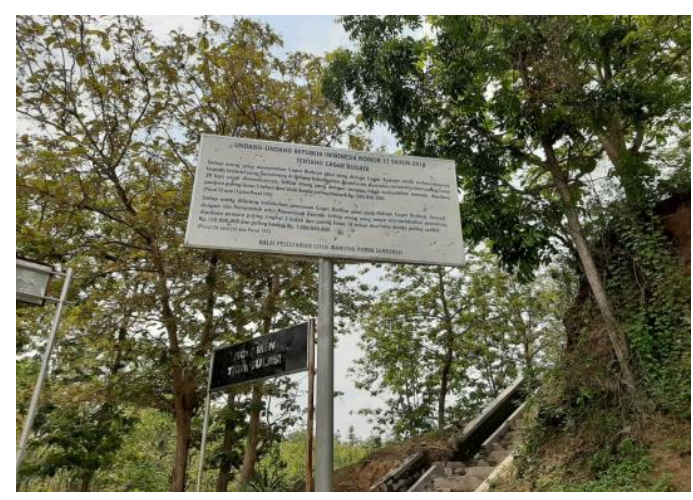

Figure 4. Warning sign and punishment threat related to cultural heritage conservation placed throughout Sangiran

Sangiran land is characteristically barren with slopes condition. If one of the owners of the land wants to flatten out his land, he could be subjected to law articles. However, Widodo said that even though the law has been implemented, he will defend his people's rights since not all of his people conceive it properly.

Yet if they violate the law, they will be punished. The same situation was also confirmed by SPD in Ngebung Village. He said, as long as it is inside Sangiran's stake, everyone must oblige the law. Like any other law, this law is implemented coercively to the people. It makes tension and distrust between people and BPSMS.

This situation is well understood by BPSMPS. According to ISB, Head of utilization section BPSMPS, there are several tensions, especially related to people perception. ISB said many of them thought that BPSMPS prohibits the local people from doing various activities in their own land. If they want to flatten the hill, they could ask recommendation from BPSMPS. BPSMPS will allow or not allow the activity after assessment to avoid damaging the land as cultural heritage.

"We are responsible to ensure the authenticity and genuine cultural heritage keep safe," Head of utilization section BPSMPS.

The existence of BPSMPS and the implementation of law was shifting the paradigm of conservation and tourism in Sangiran site. Moreover, BPSMPS actively socialized the cultural heritage law and monitoring Sangiran site condition. On another side, local people argued that they want a chance to fashion their environment. According to them, people could do any kind of activities to change their environment, for instance making a new house, 
roads, public facilities, and other infrastructure, so outsider perceived that Sangiran also making progress and growth compared with other villages in Sragen.

In the past ten years, from 2009, people have become more aware that their action takes notice not to violate the law. RTM, one of homestay owner stated nowadays Sangiran local people mostly refers to BPSMPS in various problem related to soils utilization and development. Also, every time any fossils are found, more people choose to inform BPSMPS to get financial compensation rather than keep it or sell it illegally to avoid punishment. BPSMPS and the law of cultural heritage become absorbed in Sangiran local people's minds through conversation and the theme of daily communication.

With this awareness, nowadays, local people try to focus on developing tourism while avoid dealing with Law violations. Based on our source in FGD, there are still many potentials in Sangiran other than museum. On an outer side of the Sangiran museum area, some local people devote their time to make a living of life dynamic while securing tradition by making traditional crafts such as batik and coconut shell craft, traditional snacks, a local dance, play a lesung music, and performing a wayang or shadow puppet, and developing new tourism attraction.

\section{Relation and Inter-Relation in Sangiran}

Other factors that have significant implications and consequences for Sangiran site development as a tourism destination are the pattern of relations and inter-relations among its stakeholders. In this sense, it could be portrayed more precisely by specifically focus to uncover those who get benefit from the Sangiran site the most and how it affects the Site's existence.

First, the nearest local people who live to the museum be able to create economic activity. They make souvenirs, build a unique house for a homestay, guiding assistance, open kiosk, facilitating park areas, and other things that will be needed by tourists. Meanwhile, the local people who live far from museum perceive that those who live around Sangiran Museum as the center of interest get the most benefits from Sangiran since they meet the visitors first, they can interact directly and offer many things to visitors.

Therefore, those who live far from Sangiran Museum feel that Sangiran existence has minimum advantages for them. Consequently, some are apathetic, ignorant, and isolated toward what is happening to the Sangiran site.

PWT, one of the oldest fossil founders who live in Bukuran Village said that even though he has experiences and knowledge in developing the Sangiran site and is involved in many types of research, he feels left behind and abandoned. Therefore, he has no interest in Sangiran development.

MT, one of the villagers near Manyarejo Village, $5 \mathrm{~km}$ from the main museum in Krikilan village also said while he's happy that the museum becomes well developed, he did not really bother about the tourism or the conservation. He only cares about the infrastructure development, such as road renovation and another route access in his village.

Second, in Sangiran, since 2009, Indonesia's government, through the Ministry of Education, activate Balai Pelestarian Situs Manusia Purba Sangiran (BPSMPS) in Sangiran Museum. The main duty of BPSMPS is to protect, develop, and utilize the ancient site.

BPSMPS reports the recent condition of conservation in Sangiran site regularly to UNESCO since the Sangiran as world cultural heritage was monitored. BPSMPS also socialized the Law of Cultural Heritage 2010/No. 11 and its consequences, educate the local people related to cultural heritage and fossils.

Based on the observation and interviews, Sangiran local people feel that BPSMPS is the representative of the government. Therefore, they have high expectations as well as anticipation towards BPSMPS. However, the Head of utilization section BPSMPS stated that he could not do as much as local people expected since the BPSMPS are in the third echelon under the Ministry of Education that has the authority to develop and utilize the site for the sake of conservation only.

For tourism, the Sangiran site is under the district government tourism office. While for infrastructure Sangiran site is under the regional and provincial government. According to ISB, BPSMPS is rather a newcomer in Sangiran compared to native local people who already stay in Sangiran from generation to generation. Moreover, most of BPSMPS employees came from outside the Sangiran area. Therefore, this situation is often criticized by local people [27]. Thus, many tensions can explode relations among stakeholders and local people. 


\section{Social Expectations in Sangiran Site}

Based on the primary data conducted from observation, in-depth interviews, and FGDS, it could be concluded that Sangiran local people hold various expectations related to Sangiran development. One of the expectations that often voiced is the development of infrastructure that supports tourism. Sangiran local people also hoped they could count on the government to support the package program for visitors, construct routes, and some places in Sangiran that must be visited.

In the FGDs, it was revealed that most Sangiran local people who are involved in Sangiran tourism are already accustomed to various FGDs and programs. Whether it is conducted by BPSMPS, universities, government, or other institutions to unravel problems and develop Sangiran. According to one of Krikilan Village officials, while most of the local people pessimistic that the government and other institutions could help, they also understand that each institution has its own limitation in authority to execute every plan, especially if it clashed with other institution authority. Therefore, Sangiran local people prefer to be self-supporting in developing tourism in their area. For example, Krikilan Village, which didn't want to be dependent on Museum, decided to develop a tourism village [28].

Based on FGD, there are differences in terms of expectation and readiness between the two villages, which are closest to the center of the Sangiran site. The Krikilan villagers who live near the main Sangiran museum are the most prepared and experienced to be independent. In Krikilan Village, there are saltwater spring, tingkir sanctuary, and various arts and culture potential waiting to be developed. Homestay, restaurants, and souvenir shops are already run well. Tourism Aware Group (Pokdarwis) and local youth organizations also actively make activities related to tourism development.

Respondent ARS, a Sangiran Village official, said although tourism in Krikilan is ready to develop, they still want to be guided by the experts, whether it is from government, academician, or practitioner. Meanwhile, representatives of youth organizations, homestay owners, art studio activists reckon that there are too many groups in Krikilan Village, which run independently and are not unified among them. Therefore, their expectation is on how these groups could work in synergy and involved all elements in the village to avoid the seeds of jealousy and conflict potential.

Thammajinda [29] studied that generally, people in village areas that become tourist destinations often compare themselves to others. In one case of community-based tourism location in Thailand, the community is mainly busy comparing their income than comparing what efforts have been done. This situation is what Krikilan villagers want to avoid.

Meanwhile, local people in Ngebung Village, which is located around $3 \mathrm{~km}$ from the Sangiran main museum, are not as ready as Krikilan Villagers. In the FGD, the village's apparatus said that the community in Ngebung is still getting along well. They really expect they could develop the culinary, souvenir, and home industry. However, they still need guidance and assistance from BPSMPS and the regional government.

One of the Ngebung local people (AR), explained that they want Ngebung to be as prosperous and progressive as Krikilan village. $\mathrm{He}$ dreams that a tourism concept that will be planned in Ngebung village could be bundled into one tourism package with other museum clusters in the Sangiran site. He argued that the Ngebung community also wants to make progress and make money from tourism in Sangiran. They see that Krikilan make a progress themselves without giving the opportunity to other areas in Sangiran.

The expectation of Sangiran tourism development is in line with the provincial government's expectation. Governor of Central Java, Ganjar Pranowo, explicitly express to integrate four prominent tourism destinations in his governed area into one package program [30]. One of them is Sangiran in line to Karimunjawa Island in Jepara, Dieng Hill in Wonosobo, and Borobudur Temple in Magelang. This expectation rather deviates from what BPSMPS imagine.

Respondent ISB, as BPSMPS official, described the main reason why BPSMPS placed in Sangiran is to conserve accordingly to the articles in Cultural Heritage Law 2010/No 11. One of the principles of conservation is keeping the original site unchanged. However, since BPSMPS came later than the Sangiran local people, he argued that BPSMPS cannot be too strict in implementing the law. If an area cannot be secure, the worst choice is to document the site before it is completely gone. 


\section{Governmental and Policy's Constraints}

One of the main keys in tourism management is the government, mainly because of its responsibility in regional development related to providing the conditions that must exist for sustainable tourism [31]. Apart from the government interest, according to Andriotis [32], local authorities also have a role in developing tourism. Its roles include:

1. To become the main coordinating body for strategic planning of the local tourism industry

2. Own, operate, and promote their own tourism resources and infrastructure

3. Promote their local areas as destinations and, by implication, private sector tourism products and services.

In Sangiran, the issue of development authority is crucial because it concerns who or which institution has the right to develop the site as a tourist destination. This relation of interests must be explained clearly. The relation of the interests includes UNESCO, the Ministry of Education through BPSMPS, the government of Sragen and Karanganyar district, and the Provincial Government of Central Java.

According to Aryanti and Setyowati [33], Sangiran development is also inseparable from the existence of sectoral egos of government institutions. For example, the construction of a tower of view by the Sragen Regency government has actually opened a polemic with the party that manages Sangiran.

Then there was also the district government rejection to the Governor's Decree No. $430 / 197 / 2014$ and the Minister of Education and Culture Decree No. 019/M/2015 concerning Sangiran geographic space units. A previous study described that management and utilization in Sangiran sites often become the object of conflict. It creates conflicts of interest between the local people and the government, as well as between the regional government and the central government [34]. To synchronize and unite this relationship is also not simple because it involves budget. When it comes to budgeting, the process often has to be circular and vicious. Such power relations once again need to be elaborated and formulated into a clear policy.

\section{CONCLUSION}

The existence of BPSMPS and the implementation of Cultural Heritage Law 2010/No.11 for the past ten years in Sangiran transforms various aspects of Sangiran's local people's lives. It raises any kind of tension, and it has fragmented into prejudice. It implied to the knowledge related to cultural heritage and the awareness related to responsibility conserving the site. The implementation of Cultural heritage law often becomes burdensome for Sangiran local people since it Is coercive. Local people cannot avoid the law enforcement consequences even though it disadvantages and distrusts them. This law constrains local people in develop and utilized their own land. It is the opposite of Cultural Heritage Law 2010/No.11 aims that one of the objectives of this law is to increase the social welfare among people who live surround the cultural heritage area. herefore, the Sangiran local people should develop tourism in Sangiran, that obeying the law.

Each of party who have interest in Sangiran has their own expectation which may collide with one another. The expectation of tourism development may collide with the conservation principle that must be applied in World Heritage Site. In this case, both expectations must be fulfilled and synchronize to create the ideal heritage tourism.

Other than the constrain from the Cultural Heritage law, Sangiran development also obstructed by the government's seriousness and synergy. Therefore, a clear policy related to every stakeholder role in Sangiran must be formed.

\section{ACKNOWLEDGEMENT}

The author would thank the Institute for Research and Community Service of the University of Pembangunan Nasional "Veteran" Yogyakarta, who fund this research.

\section{REFERENCES}

[1] Hakim, L. and N. Nakagoshi. 2008. Planning for nature-based tourism in East Java: recent status of biodiversity, conservation, and its implication for sustainable tourism. ASEAN Journal of Hospitality and Tourism 7, 155-167.

[2] Solima, L. and A. Minguzzi. 2014. Territorial development through cultural tourism and creative activities. Mondes du Tourism 10, 6-18. DOI: 10.4000/tourisme.366.

[3] Timothy, D. J. and G. P. Nyaupane. 2009. Cultural heritage and tourism in the developing world a regional perspective. Routledge. New York.

[4] Jones, T., M. Hughes, V. Peel, D. Wood, and W. Frost. 2007. Assisting communities to develop heritage tourism opportunities. 
Cooperative Research Centre for Sustainable Tourism. Australia.

[5] Indonesian Ministry of Education and Culture. 1997. Ministry Decision No. 070/0/1977 about Cultural Conservation or Heritage Area of Sangiran. Ministry of Education and Culture. Jakarta.

[6] Sulistyanto, B. 2009. Warisan dunia Situs Sangiran persepsi menurut penduduk Sangiran. Jurnal Wacana 11(1), 57-80.

[7] Statistic Center of Sragen Regency. Jumlah pengunjung dan pendapatan obyek pariwisata musium Sangiran. Available at: https://sragenkab.bps.go.id/statictable/201 6/11/25/249/jumlah-pengunjung-danpendapatan-obyek-pariwisata-musiumsangiran-2015.html.

[8] Hazliansyah. 2018. Pengunjung museum Purbakala Sangiran terus meningkat (October $31^{\text {st }}$ ). Available at: https://republika.co.id/berita/phgmyq280/ pengunjung-museum-purbakala-sangiranterus-meningkat.

[9] UNWTO. 2005. Cultural tourism and poverty alleviation: the Asia-Pacific perspective. World Tourism Organization. Madrid.

[10] Kurniawan, D. A., and Nasiwan. 2015. Kondisi sosial masyarakat krikilan pasca pengembangan obyek wisata Museum Sangiran Tahun 2012-2016. Social Studies 7(2), 119-134.

[11] Afandi, R. L. and M. M. Ali 2015. Kajian pengaruh keberadaan Kawasan Wisata Sangiran terhadap aspek fisik, aspek ekonomi, dan aspek sosial masyarakat. Jurnal Teknik PWK 4(2),282-292.

[12] Sugiarti, R., Warto, and T. W. Sutirto. 2019. Partisipasi pemangku kepentingan dalam mendukung revitalisasi aset wisata pusaka di Kawasan World Heritage Sangiran. Cakra Wisata 20(2), 17-34.

[13] Mulyantari, E. 2016. Strategi pengembangan Situs Manusia Purba Sangiran sebagai daya tarik wisata budaya. Jurnal Media Wisata 14(1), 333-344.

[14] Sukronedi and Haryono. 2015. Situs Sangiran: potensi, problematika, dan strategi pelestariannya. Buletin Kudungga Vol. 4. BPCP. Samarinda.

[15] Raharjo, S. 2013. Beberapa permasalahan pelestarian kawasan cagar budaya dan strategi solusinya. Jurnal Konservasi Cagar Budaya Borobudur 7(2), 4-17.

[16] Prasetyo, B. 2018. Efektifitas pelestarian cagar budaya dalam Undang-Undang
Nomor. 11 Tahun 2010 tentang cagar budaya. Jurnal Legislasi Indonesia 15(1), 6978.

[17] Ningrum, N. S., U. S Hardjanto, and E. S. Prihatin. 2016. Pengelolaan cagar budaya di Museum Ronggowarsito menurut UndangUndang Republik Indonesia Nomor 11 Tahun 2010 tentang cagar budaya. Diponegoro Law Review 5(2), 1-11.

[18] Herawati, R. 2016. Implementasi UndangUndang Nomor 11 Tahun 2010 terhadap pelestarian benda cagar budaya di Kecamatan Ambarawa Kabupaten Semanrang. Humani 6(1), 59-73.

[19] Mohajan, H. K. 2018. Qualitative research methodology in social sciences and related subjects. Journal of Economic Development, Environment and People 7(1), 23-48.

[20] Brunt, L. 2007. Into the Community. In: Atkinson, P., A. Coffey, S. Delamont, J. Lofland, and L. Lofland (Eds). Handbook od Ethnography, 80-91. Sage. London.

[21] Fitzpatrick, K. 2013. Why critical ethnography? Counterpoints Vol. 432, Critical Pedagogy, Physical Education and Urban Schooling, 25-52.

[22] Ryan, G. S. 2017. An introduction to the origins, history and principles of ethnography, Nurse Researcher 24(4), 15 21.

[23] Ratnawati, V. 2019. Counseling values in the treasury of Javanese ethics (an observation towards the Javanese in implementing Javanese ethics education which is relevant to counseling values in life). Advances in Social Science, Education and Humanities Research 287, 27-32.

[24] Fang, W. T., E. Ng, C. M. Wang, and M. L. Hsu. 2017. Normative beliefs, attitudes, and social norms: People reduce waste as an index of social relationships when spending leisure time. Sustainability 9, 1696. DOI: $10.3390 /$ su9101696.

[25] Suyanto, S. and B. Pudjianto. 2015. Pemberdayaan masyarakat menuju desa sejahtera (studi kasus di Kabupaten Sragen). Sosio Konsepsia 5(1), 340-354.

[26] Republic of Indonesia. 2010. Law No. 11/ 2010 on Cultural Conservation. Republic of Indonesia. Jakarta.

[27] Duhri, M. K. 2020. Dikritik karena pegawai didominasi warga luar daerah, ini jawaban BPSMP Sangiran. Available at: https://m.solopos.com/dikritik-karena- 
pegawai -didominasi-warga-luar-daerah-inijawaban-bpsmp-sangiran-1049163.

[28] Duhri, Muh Khodiq. 2020. Tak Mau Bergantung Ke Museum Sangiran, Krikilan Sragen Kembangkan Desa Wisata. https://www.solopos.com/tak-maubergantung-ke-museum-sangiran-krikilansragen-kembangkan-desa-wisata-1070146

[29] Thammajinda, R. 2013. Community participation and social capital in tourism planning and management in a Thai context. Lincoln University. New Zealand.

[30] Nurdin, N. 2018. Ganjar andalkan 4 destinasi, Sudirman bakal bentuk wisata (April 10 $10^{\text {th }}$ ). Available at: https://regional.kompas.com/read/2018/04 /10/14572731/ganjar-andalkan-4-destinasisudirman-bakal-bentuk-klusterwisata?page=all.

[31] Vieira, I., A. Rodrigues, D. Fernandes, and C. Pires. 2016. The role of local government management of tourism in fostering residents' support to sustainable tourism development: evidence from a Portuguese historic town. International Journal of Tourism Policy 6(2), 109-135.

[32] Andriotis, K. 2001. Tourism planning and development in Crete: recent tourism policies and their efficacy. Journal of Sustainable Tourism 9(4), 298-316.

[33] Aryanti, O. F. D. and K. Setyowati. 2018. Kerjasama antar daerah dalam pengembangan pariwisata Kawasan Sangiran. Jurnal Litbang Sukowati 2(1), 106117.

[34] Huda, M. A., R. A., Bawono, and Zuraidah. 2017. Persepsi dan partisipasi publik dalam upaya pemanfaatan Museum Situs Sangiran berbasis masyarakat. Jurnal Humanis 19(1), 124-131. 